Editorial

\title{
Climate Policy in a Fragmented World-Transformative Governance Interactions at Multiple Levels
}

\author{
Anne Jensen ${ }^{1}$, Helle Ørsted Nielsen ${ }^{1}$ and Duncan Russel ${ }^{2, *}$ \\ 1 Department of Environmental Science, Aarhus University, 8000 Aarhus C, Denmark; aj@envs.au.dk (A.J.); \\ hon@envs.au.dk (H.Ø.N.) \\ 2 Department of Politics, Exeter University, Exeter EX4 4PY, UK \\ * Correspondence: d.j.russel@exeter.ac.uk
}

Received: 10 November 2020; Accepted: 11 November 2020; Published: 30 November 2020

\section{Background}

The call for fundamental changes to meet the challenges of climate change is rising across scientific disciplines, communities, and countries. Transformative changes to our politics, society and economy are needed to rapidly cut greenhouse gas emissions to mitigate the most dangerous forms of climate change [1]. At the same time, societies must adapt to the massive impacts of a changing climate [2], impacts that occur within an immediate time horizon will generate significant economic, social and environmental costs. Public actions at multiple governance levels tend to be incremental at the outset, and it can be difficult to maintain the momentum for the transformative changes required. One of the crucial factors determining whether the necessary change occurs is the extent to which policy is suitably targeted at the problem.

Climate policy is a problem of collective action par excellence, which necessitates government responses from the local to the super-national levels. However, climate policy is multi-dimensional, and centers on different objectives in relation to climate change mitigation and adaptation, respectively. Moreover, climate policy is linked to a number of other policy areas where political attention and priorities also differ, all adding to the creation of challenges for collective solutions. The synergies between climate change mitigation and adaption policy are argued to be few and far between, especially as they both differ across societal levels and spatial and temporal scales. Climate change mitigation policy requires an immediate collective global response but the results of any policy interventions will probably not be seen until many years in the future. This is tentatively illustrated by the recent COVID-19 pandemic, where a limited but significant drop in green-house gas (GHG) emissions has failed to place any observable breaks in the long-term climate change trajectory. Moreover, climate mitigation requires a fundamental change in our societies and economies as carbon intensive technologies have become the backbone of our societies, economics, and, as a result, modern life [3]. By contrast, climate adaptation policy, on the whole, has a different orientation. The impacts of climate (e.g., draughts and heatwaves, etc.) are distributed unequally across the globe and vulnerability varies greatly at the local scale, with small island states and melting icecaps presenting prime examples. Climate adaptation policy needs to thus be suited to the local context and can occur independently at local and national levels (i.e., a global response alone is deficient). Furthermore, it is an approach that can reap immediate rewards, as it can, through policies and actions designed and implemented by local governance, immediately enhance the resilience of relevant social, economic, and ecological communities.

Crucially, both climate adaptation and mitigation policies involve engagement with a wide range of other sectors, which, for example, has induced the European Union (EU) to specify climate policy 
integration and mainstreaming as mandatory in its recent climate adaptation strategy. In a resource constrained environment, which has been particularly acute since the 2008 credit crisis and looks to be more so given the economic fallout from COVID-19, adaptation and mitigation are both competing for attention and resources, with few opportunities for win-win policies that address both. Thus, while there is tendency to lump climate policy together, in reality, policy makers are faced with the prospect of deciding where resources would be best directed.

There are also questions regarding how climate mitigation and adaptation policies play out across different governance levels. For instance, in the United Kingdom, the central government has undertaken a strong lead in climate mitigation policy but has devolved responsibility for adaptation to regions and sectors yet with little financial backing [4]. While transformative change is needed across governance levels, it is clear that fragmented governance settings, where different levels of governance, institutions and policy sectors are not moving in the same direction, can hamper progress. Against this fragmented background within and between sectors and levels of governance, this Special Issue brings together a collection of papers exploring the challenges of transformative climate policy in different governance settings. This introductory paper focuses on the three pertinent themes that structure the Special Issue, namely (1) transformative climate policy, (2) multi-level governance and (3) policy coordination/integration. Specifically, it examines how the interactions of these themes impact upon the effectiveness of climate policy and aims to identify the key dynamics in an overview of current and apposite research topics.

\section{Transformative Change and the Dynamics of Policy Making}

In a nutshell, climate policy is about ensuring a resilient global social-ecological system that has the ability to change and adapt, while maintaining the same functions and structure [5], i.e., to avoid crossing critical thresholds that change planetary systems and as a consequence undermine well-being. As a response, Folke et al. [6] argue that a transformational change is required which commands the capacity "to cross thresholds into new development trajectories" [6] (p. 1). While transformative change suggests radical action, it does not necessarily imply sudden, large-scale change. Transformative change and the associated societal changes should induce a "shift in the governance landscape" [7], often requiring a change in the approach of politics and policies, which has been termed experimental politics or innovative governance [7-9]. It has been argued that local-level experimentation is particularly well-suited to developing and testing novel solutions and thus to facilitate the development of longer-term transformative change [5,6,10,11] (Contribution 4).

However, the nature of policy making may not be conducive to transformative change, especially in the complex policy fields of climate mitigation and adaptation. When looking for transformative policy solutions, the climate problem is often portrayed by scientists and policy advocates alike as one where the solutions are readily available and that it is simply a matter of instrumentally feeding the latest science into the policy process $[12,13]$. However, climate policy is a complex, knowledge intensive policy area that cuts across many public and private interests, many societal sectors and interlinked processes associated with production, consumption, trade, travel, and daily life [7]. These conditions mean that policy is more susceptible to being side-lined or weakened to the extent that it falls short of what the latest science suggests is needed, because action requires a solid understanding of threats and policy solutions, and because the intersection with other interests implies either potential conflicts or a lack of prioritization. Moreover, the literature on climate policy specifically, and public policy more generally, argues that an instrumental view of climate policy is likely to be the exception rather than the norm [14]. Public policy scholars have often pointed to the recursive nature of policy making, which is dominated by the compromise of interested parties, and thus, leads to incremental rather than transformative change [15]. Indeed, compromise is needed regarding how to spend limited public finances and, likewise, over questions of how to prioritize between different-often also pressing-areas of public interest within the confines of electoral cycles [16]. In this sense, climate policy has to compete with other, often shorter-term, possibly conflicting, policy goals, which tend 
to be ranked highly by the electorate (e.g., economy, welfare services and health) [17]. However, incrementalism also stems from the difficulty associated with bounded rational actors handling complex policy problems under conditions of uncertainty [18]. From this perspective, incremental policy making, per se, does not exclude transformative change as a step-by-step process that facilitates learning and development. The questions remain, though, regarding just how incremental or novel such approaches are, and how they are integrated and institutionalized into existing policy making processes. In this respect, Granberg et al. (Contribution 4) suggest that small-scale changes in climate adaptation at the local level can be connected and amplified to bring about transformative change at a regional scale, because the regional level uses knowledge across localities to unblock entrenched policies and practices.

\section{Levels of Governance}

Policy makers and climate governance scholars have engaged in a longstanding discussion about the roles of different policy levels in climate governance, particularly what governance level can most effectively address climate policy problems [19-22], to facilitate the necessary transformative change. Conventional collective action theory suggests that climate mitigation requires a global treaty [19]. While individual countries can develop climate policies and make the necessary transformations towards a low carbon economy, this may have little impact on climate change unless a global approach is taken that meaningfully includes the largest greenhouse gas emitters. This, in turn, suggests that no governments will take action without global regulation, i.e., externally enforced requirements [19].

However, an alternative strand in the governance literature argues that cities and local communities may be the most suitable entry point for tackling climate problems $[16,23]$ because the local level is better suited to experiment and develop new solutions (see [6,19,21,24] (Contribution 4) for discussions). Moreover, they claim that cities, contrary to theoretical expectations, have become de facto leaders in climate policy development and implementation $[8,23,25]$. While cities are embedded in national and international governance regimes and systems, and thus their governing capacity is dependent on specific divisions of responsibilities and competencies vis-a-vis other government levels within a system of multilevel governance [20], they can be less constrained by national budgets, large and complex administrations, political coalitions and competing interests. In the US, for example, many cities and states set objectives and commit to $\mathrm{CO}_{2}$ reduction targets that go far beyond the federal government, and cities such as Copenhagen or Leipzig framed climate mitigation and adaptation as strategic concerns backed by the allocation of resources prior to national and European political commitments $[8,13,26]$ (Contribution 1).

Ostrom [19] argues that in fact climate governance offers potential benefits across multiple scales, providing incentives for lower level action even in the absence of global coordination. Climate mitigation policy may provide a local window for promoting green businesses and technologies. Nonetheless, a recurrent question in the literature queries whether the perception of cities as the leaders in climate policy making is created by a few shining and well-branded examples, or whether this perception is reflected by the activities of a vast majority of small, medium and even large cities across the world [21]. With regard to climate adaptation, the local incentive to undertake action would appear even stronger as local communities face immediate benefits from taking adaptive measures, be it measures to prevent damage from flooding or adapting agriculture to higher temperatures and different precipitation patterns. However, to ensure the most efficient solutions, adaptation policies also point to action across multiple levels of government as well as regional solutions that coordinate upstream and downstream communities. The collective action problem not only relates to the levels of governance, but is also linked to the roles that individuals, organizations and businesses attain vis-à-vis public administrations. Indeed, it is the wealthiest individuals who most highly contribute to greenhouse gas emissions and the poorest who will be most affected by climate impacts, regardless of where they live.

Moreover, there is the crucial issue of borders when considering the positive and negative spillover effects of policy. For instance, high climate standards can spill over into neighboring countries in a 
race to the top, as can be seen in many European countries or at inter- or intrastate level in the United States $[9,27]$. In such situations, administrations can learn from each other, leading to policy ideas being transferred from one jurisdiction to another [8] (Contribution 4). Trading relationships can particularly lead to higher standards as countries with ambitious climate change goals, strong economies and large markets demand higher standards from imports. However, policy spillovers can also be negative. Rather than a race to the top situation, states can competitively weaken their climate policy to be more economically efficient than their neighbors and rivals. Strong climate policies in some regions could also push the production of high carbon products (i.e., steal production) to regions with weaker policies and thus costs—so called carbon leakage [28].

Altogether then, climate change presents a multi-level governance challenge. It is multilevel in that it connects policy action from the most local level to the international level [23]. It is a governance challenge as it not only involves the actions of government actors but is also dependent on the behavior of a myriad of private actors from individuals and local communities through to corporations [8]. Rather than the question of what level can best address climate change, then, such a situation suggests questions regarding how to ensure an appropriate distribution of decision-making competencies and how to ensure coordination across actors. In order to reap the benefits of multi-level governance, studies have shown the political and institutional space surrounding climate change challenges to be a critical factor for actors across different levels [24]. For local actors, this could mean having decision-making power over relevant aspects of climate policy, but it also could mean that there needs to be a national or international/interstate framework to support local action [29]. Likewise, from the international perspective, e.g., the United Nations or the European Union, there must be mechanisms in place that ensure implementation on the ground. In other words, actors across all levels of governance must possess appropriate governance resources, capacity, and competencies. Overall, therefore, the multilevel governance nature of climate politics challenges national and local/city level policy making to bridge jurisdictional and politico-cultural boundaries across levels of policy making.

\section{Policy Coordination, Integration, Spillovers}

Within this multi-level context, the challenges of climate change as a highly specialized and complex problem necessitate hard decisions and cannot be managed through actions within one policy sector alone - and thus is a wicked problem — creating the challenge of better coordinating or integrating policy [30]. Academic literature is rife with examples of how to address this coordination problem (e.g., [30,31]), mainly through the concept of climate policy integration, which seeks to better coordinate policy making between the sectors [32-34]. Vertical integration links to the different levels of policy making are discussed above, while horizontal integration concerns the inclusion of climate policy issues between relevant policy sectors and levels. Broadly, climate policy integration is a strategy that employs a number of administrative processes (e.g., inter-sectoral consultation or cross-sector procedures) and instruments (e.g., ex ante impact assessment) to ensure that climate goals are factored into sectoral policies at the earliest opportunity (see for example Contribution 1 this issue). Candel and Biesbroek [34] argue that policy integration enhances the effectiveness of policy making through the reduction in duplication and contradictions between different policy sectors, and indeed also through a political function where goals and policy ideas are aligned at a strategic level in policy institutions. Policy integration also guides attention to trade-offs in other sectors that may drive climate policies forward at a higher pace and a higher level of political commitment. As a deep principle of policy, climate policy integration may, however, at any time, conflict with other political values that prevail in national/local policy institutions. Crucially, it is unclear at which governance level policy integration is best aimed for mainstreaming climate policy, and how different strategies occurring at different governance levels interact to compliment or undermine each other.

Spillovers can also occur between different policy sectors at different governance levels. For instance, it is frequently documented how ambitious climate mitigation or adaptation goals can be undermined by actions in cognate sectors [30,34]. Decisions on land-use planning, for example, 
can either facilitate or undermine climate mitigation goals, depending on the provision of public transport, distance to amenities, jobs and services, urban design favouring private road transport over active forms of travel or less transport, suburban housing over densification, etc. Likewise, climate change adaptation goals can be undermined by policies in other sectors, with for instance in situ biological conservation policy contradicting the adaptation need for species to migrate northwards in response to a changing climate, or agricultural production over water retention. Frequently, conflicting governing rationalities and institutionalized sector interests can lead to opposing goals and interventions, where policy actors seek to overcome such barriers inter alia through framing climate policy in terms of co-benefits and cross-sector common strategies or visions, through coordination via national frameworks, or formalized procedures for monitoring or collaboration [26,30] (Contribution 1).

Policy integration across sectors, or horizontal coordination, also involves action by many types of non-governmental actors, including businesses, third sector organizations, and private citizens, constituting horizontal networks of actors including or interacting with government actors, which presents further coordination challenges. This differentiation of actor constellations offers both opportunities and challenges. Stakeholder participation is said to improve both the democratic legitimacy of policy making as well as the effectiveness of policies as stakeholders provide information leading to higher quality decisions $[35,36]$. However, the participatory processes also pose challenges. Participatory procedures are selective in their design for specific types of stakeholders/citizens. A particular issue related to participatory governance is power differentials between participants, which affect the participatory processes [37]. Participants may differ in resources, be it time, education, socio-demographic status, or institutional position [37], which affects their ability and perhaps willingness to participate or shape policies. Differences in resources of participants and the capacity to engage in the policy making process in turn affects perceptions of processual legitimacy and, ultimately, trust. Likewise, Storbjörk et al (this issue) (Contribution 5) find that the effectiveness of climate policy may suffer when powerful stakeholders are able to negotiate the implementation of policies that support their interests. Furthermore, dispersing decision-making powers to include non-elected officials may blur the lines of accountability [35]. The question is whether elected officials should or would, and to which degree, turn over decision-making powers to actors who represent only a subset of a community. Stakeholder involvement requires time, and unless stakeholders feel that their participation makes a difference, their motivation to participate is likely to diminish [35,37]. Moreover, stakeholder participation raises the stakes of coordination, as vertical and horizontal networks could intersect. Formal coordination fora with access to key social and political scales may help ensure alignment between the interests and goals of different actors regarding climate issues, including political-administrative decision-makers and wider governance stakeholders.

\section{Special Issue Outline}

Within the context of transformative politics, multilevel governance and climate policy coordination/integration, the papers featured in this Special Issue explore the prospect of climate policy in the context of overarching policy frameworks, and at different governance levels from the EU (Contribution 1), through to the nation state (Contribution 6) and regional and local initiatives [11] (Contribution 2,5). Most of the papers explore the issue of transformation through the lens of climate change adaptation, with the exception of Thorman et al. (Contribution 3), who are interested in mitigation of climate change in relation to consumption. Thorman et al. (Contribution 3) are also the only contributors who actively take a multi-level approach from the individual to the nation state (Contribution 3), with the other contributors focusing on a particular level while taking the multi-level context into account. The papers also consider a mix of different actors, from public authorities [11] (Contribution 1,2) through to individuals (Contribution 3) and collaborative approaches between public and private partners (Contribution 5,6). Policy coordination is a feature of the majority of the papers, whether it is between governance levels (e.g., Contribution 2), policy sectors (e.g., Contribution 1) or between public and private bodies (e.g., Contribution 5). The papers tend to be concentrated 
on Europe with the exception of Holler et al.'s paper (Contribution 6), which focuses on the least developed nations in the world, and Granberg et al.'s paper (Contribution 4), which features a case study in Australia.

In their study of climate change adaptation coordination in selected European Union member states, Russel et al. (Contribution 1) argue that climate change adaptation is best suited to the local and sectoral governance levels so that adaptation responses can be tailored to the specific contexts of geography and socio-economic conditions. However, they show that national and supra-national frameworks are important to produce more coordinated policy approaches. Due to existing institutional hierarchies and decision rules, they find longer-term opportunities for managing conflicts and synergies among sectoral policies to facilitate transformative climate policy have to date been limited. Similar to Russel et al. (Contribution 1), Holler et al. (Contribution 6) focus on national climate change adaptation, but instead of focusing on wealthy European states, they examine the approaches of 50 of the world's poorest nations and, in particular, the role of stakeholders. They find that national adaptation planning in these countries was under-resourced with little opportunity for stakeholder engagement-despite this being a central tenant of the proposed approaches-and limited transformative change. Mocca et al. (Contribution 2) focus on Vienna as an example of urban sustainability and identify a number of barriers to multi-level policy coordination. They argue that critical policy windows of opportunity created the conditions for Vienna to take steps towards transformative techno-managerial approaches to climate change. Thorman et al. (Contribution 3) explore how policy support at different levels of government might impact upon the lifestyle of individuals. They find that support for more radical transformative climate mitigation policy at the national and community levels of governance can be enhanced with information provision on the harmful impact of consumption. Granberg et al. (Contribution 4) focus on climate policy adaptation case studies in Victoria, Australia and the Gothenburg region, Sweden. They argue that transformative adaptation policy requires policy interventions at regional as well as local scales to better connect across governance levels in terms of knowledge, values and organization remits, to unlock local level small scale wins and to remove institutional blockages. Storbjörk et al. (Contribution 5) focus on transformative climate adaptation policy in six centralized Swedish municipalities. They highlight the importance of coordination processes to enhance dialogues between public authorities and private actors (property developers) in the planning process to improve the effectiveness of adaptation policy implementation.

While not generalizable, because a comparative research design was not strictly prescribed, the contents of the papers are informative in providing evidence and insights on recent climate policy that demonstrate the interplay between these three themes outlined above.

\section{List of Contributions}

1. Russel, D.; Castellari, S.; Capriolo, A.; Dessai, S.; Hildén, M.; Jensen, A.; Karali, E.; Mäkinen, K.; Nielsen, H. Ørsted; Weiland, S.; et al. Policy Coordination for National Climate Change Adaptation in Europe: All Process, but Little Power.

2. Mocca, E.; Friesenecker, M.; Kazepov, Y. Greening Vienna. The Multi-Level Interplay of Urban Environmental Policy-Making.

3. Thorman, D.; Whitmarsh, L.; Demski, C. Policy Acceptance of Low-Consumption Governance Approaches: The Effect of Social Norms and Hypocrisy.

4. Granberg, M.; Bosomworth, K.; Moloney, S.; Kristianssen, A.-C.; Fünfgeld, H. Can Regional-Scale Governance and Planning Support Transformative Adaptation? A Study of Two Places.

5. Storbjörk, S.; Hjerpe, M.; Glaas, E. Take It or Leave It": From Collaborative to Regulative Developer Dialogues in Six Swedish Municipalities Aiming to Climate-Proof Urban Planning.

6. Holler, J.; Bernier, Q.; Roberts, J.T.; Robinson, S-A. Transformational Adaptation in Least Developed Countries: Does Expanded Stakeholder Participation Make a Difference? 
Author Contributions: Conceptualization, A.J., H.Ø.N. and D.R.; writing—original draft preparation, A.J., H.Ø.N. and D.R.; writing-review and editing, A.J., H.Ø.N. and D.R.; All authors have read and agreed to the published version of the manuscript.

Funding: This research received no external funding.

Conflicts of Interest: The authors declare no conflict of interest.

\section{References}

1. Intergovernmental Panel on Climate Change. Special Report: Global Warming of $1.5^{\circ}$; IPPC: Switzerland, Geneva, 2018.

2. Sanderson, H.; Hildén, M.; Russel, D.; Penha-Lopes, G.; Capriolo, A. (Eds.) Adapting to Climate Change in Europe; Elsevier: Amsterdam, The Netherlands, 2018; pp. 273-313.

3. Urry, J. The 'System' of Automobility. Theory Cult. Soc. 2004, 21, 25-39. [CrossRef]

4. Van Der Heijden, J.; Patterson, J.; Juhola, S.; Wolfram, M. Special section: Advancing the role of cities in climate governance-Promise, limits, politics. J. Environ. Plan. Manag. 2018, 62, 365-373. [CrossRef]

5. Uyl, R.M.D.; Russel, D. Climate adaptation in fragmented governance settings: The consequences of reform in public administration. Environ. Politi 2017, 27, 341-361.

6. Folke, C.; Carpenter, S.R.; Walker, B.; Scheffer, M.; Chapin, T.; Rockström, J. Resilience Thinking: Integrating Resilience, Adaptability and Transformability. Ecol. Soc. 2010, 15, 20. [CrossRef]

7. Bulkeley, H.; Coenen, L.; Frantzeskaki, N.; Hartmann, C.; Kronsell, A.; Mai, L.; Marvin, S.; McCormick, K.; Van Steenbergen, F.; Palgan, Y.V. Urban living labs: Governing urban sustainability transitions. Curr. Opin. Environ. Sustain. 2016, 22, 13-17. [CrossRef]

8. Shove, E.; Walker, G. Caution! Transitions Ahead: Politics, Practice, and Sustainable Transition Management. Environ. Plan. A Econ. Space 2007, 39, 763-770. [CrossRef]

9. Hughes, S.; Chu, E.K.; Mason, S.G. (Eds.) Climate Change in Cities. Innovations in Multi-Level Governance; Springer: Cham, Switzerland, 2018.

10. Ehnert, F.; Kern, F.; Borgström, S.; Gorissen, L.; Maschmeyer, S.; Egermann, M. Urban sustainability transitions in a context of multi-level governance: A comparison of four European states. Environ. Innov. Soc. Transit. 2018, 26, 101-116. [CrossRef]

11. Huitema, D.; Jordan, A.; Munaretto, S.; Hildén, M. Policy experimentation: Core concepts, political dynamics, governance and impacts. Policy Sci. 2018, 51, 143-159. [CrossRef] [PubMed]

12. Bernstein, S.; Hoffmann, M. The politics of decarbonization and the catalytic impact of subnational climate experiments. Policy Sci. 2018, 51, 189-211. [CrossRef]

13. Iyalomhe, F.; Jensen, A.; Critto, A.; Marcomini, A. The Science-Policy Interface for Climate Change Adaptation: The Contribution of Communities of Practice Theory. Environ. Policy Gov. 2013, 23, 368-380. [CrossRef]

14. Corfee-Morlot, J.; Cochran, I.; Hallegatte, S.; Teasdale, P.-J. Multilevel risk governance and urban adaptation policy. Clim. Chang. 2010, 104, 169-197. [CrossRef]

15. Dunlop, C.A. The Possible Experts: How Epistemic Communities Negotiate Barriers to Knowledge Use in Ecosystems Services Policy. Environ. Plan. C Gov. Policy 2014, 32, 208-228. [CrossRef]

16. Lindblom, C.E. Still Muddling, Not Yet Through. Public Adm. Rev. 1979, 39, 517-526. [CrossRef]

17. Hughes, S. The Politics of Urban Climate Change Policy: Toward a Research Agenda. Urban Aff. Rev. 2017, 53, 362-380. [CrossRef]

18. Russel, D.; Benson, D. Green budgeting in an age of austerity: A transatlantic comparative perspective. Environ. Politi. 2014, 23, 243-262. [CrossRef]

19. Lindblom, C.E. The Science of "Muddling Through". Public Adm. Rev. 1959, 19, 79-88. [CrossRef]

20. Ostrom, E. Polycentric systems for coping with collective action and global environmental change. Glob. Environ. Chang. 2010, 20, 550-557. [CrossRef]

21. Bulkeley, H.; Betsill, M. Rethinking Sustainable Cities: Multilevel Governance and the 'Urban' Politics of Climate Change. Environ. Politi 2005, 14, 42-63. [CrossRef]

22. Jordan, A.J.; Huitema, D.; Hildén, M.; Van Asselt, H.; Rayner, T.J.; Schoenefeld, J.J.; Tosun, J.; Forster, J.; Boasson, E.L. Emergence of polycentric climate governance and its future prospects. Nat. Clim. Chang. 2015, 5, 977-982. [CrossRef] 
23. Betsill, M.; Bulkeley, H. Looking Back and Thinking Ahead: A Decade of Cities and Climate Change Research. Local Environ. 2007, 12, 447-456. [CrossRef]

24. Biesbroek, R.; Lesnikowski, A. Adaptation. In Governing Climate Change: Polycentricity in Action? Forster, J., Jordan, A., Huitema, D., Van Asselt, H., Eds.; Cambridge University Press: Cambridge, UK, 2018; pp. $303-319$.

25. Kern, K. Cities as leaders in EU multilevel climate governance: Embedded upscaling of local experiments in Europe. Environ. Politi 2019, 28, 125-145. [CrossRef]

26. Jensen, A.; Van Bommel, S.; Pedersen, A.B.; Nielsen, H. Ørsted; Kuindersma, W. Framing climate change: New directions in Dutch and Danish planning strategies. Plan. Theory Pract. 2013, 14, 233-247. [CrossRef]

27. Salon, D.; Murphy, S.; Sciara, G.-C. Local climate action: Motives, enabling factors and barriers. Carbon Manag. 2014, 5, 67-79. [CrossRef]

28. Eichner, T.; Pethig, R. Carbon Leakage, the Green Paradox, and Perfect Future Markets. Int. Econ. Rev. 2011, 52, 767-805. [CrossRef]

29. Keskitalo, E.C.H.; Juhola, S.; Baron, N.; Fyhn, H.; Klein, J. Implementing Local Climate Change Adaptation and Mitigation Actions: The Role of Various Policy Instruments in a Multi-Level Governance Context. Climate 2016, 4, 7. [CrossRef]

30. Peters, B.G. The challenge of policy coordination. Policy Des. Pract. 2018, 1, 1-11. [CrossRef]

31. Persson, Å.; Runhaar, H.; Karlsson-Vinkhuyzen, S.; Mullally, G.; Russel, D.; Widmer, A. Editorial: Environmental Policy Integration: Taking stock of policy practice in different contexts. Environ. Sci. Policy 2018, 85, 113-115. [CrossRef]

32. Adelle, C.; Russel, D. Climate Policy Integration and Environmental Policy Integration: A case of déjà vu? Environ. Policy Gov. 2013, 23, 1-12. [CrossRef]

33. Jordan, A.; Lenschow, A. Environmental policy integration: A state of the art review. Environ. Policy Gov. 2010, 20, 147-158. [CrossRef]

34. Candel, J.J.L.; Biesbroek, R. Toward a processual understanding of policy integration. Policy Sci. 2016, 49, 211-231. [CrossRef]

35. Huitema, D.; Mostert, E.; Egas, W.; Moellenkamp, S.; Pahl-Wostl, C.; Yalcin, R. Adaptive Water Governance: Assessing the Institutional Prescriptions of Adaptive (Co-)Management from a Governance Perspective and Defining a Research Agenda. Ecol. Soc. 2009, 14, 26. [CrossRef]

36. Newig, J.; Fritsch, O. Environmental governance: Participatory, multi-level-And effective? Environ. Policy Gov. 2009, 19, 197-214. [CrossRef]

37. Sharma-Wallace, L.; Velarde, S.J.; Wreford, A. Adaptive governance good practice: Show me the evidence! J. Environ. Manag. 2018, 222, 174-184. [CrossRef] [PubMed]

Publisher's Note: MDPI stays neutral with regard to jurisdictional claims in published maps and institutional affiliations.

(C) 2020 by the authors. Licensee MDPI, Basel, Switzerland. This article is an open access article distributed under the terms and conditions of the Creative Commons Attribution (CC BY) license (http://creativecommons.org/licenses/by/4.0/). 